\title{
NMR VELOCITY MAPPING AND RHEO-NMR IN COMPLEX LIQUIDS
}

\author{
U. EICHHOFF, ${ }^{1}$ K. $\mathrm{ZICK}^{1}{ }^{1}$ P.T. CALLAGHAN ${ }^{2}$ \\ ${ }^{1}$ Bruker BioSpin GmbH, Rheinstetten \\ (Germany) \\ 2Victoria University of Wellington \\ (Wellington, New Zealand)
}

By using the NMR technique, we have determined the velocity distribution and the rate of strain in a micelle solution (cetylpyridinium chloride and sodium salicylate) below and above a critical shear rate and have studied the isotropic and stress-induced ordered nematic phases in a micelle solution CTAB $/ \mathrm{D}_{2} \mathrm{O}$ in a cylindric Couette cell.

\section{Introduction}

NMR is a unique analytical technique and has been awarded directly with four Nobel prizes in the fields of physics (1952:Bloch,Purcell), chemistry (1991:Ernst, 2002:Wüthrich), and medicine (2003:Lauterbur,Mansfield). MR-imaging has become a key technology in medical diagnosis, but it can be applied as well in materials science. It is an ideal tool to study the properties of complex liquids, because it can selectively image the spin density, relaxation, diffusion, displacement of molecules, velocity, acceleration, strain, and stress.

\section{Basis of NMR-Imaging}

The NMR resonance frequency is proportional to the magnetic field strength. If two linear gradients will be superimposed on the static magnetic field, the resonance frequency and the phase of a signal will depend on the location of spins. For a two-dimensional experiment, the $x$-gradient $G_{x}$ encodes the frequency in the $x$-direction and an additional $y$-gradient $G_{y}$ encodes the phase in the $y$-direction. The image reconstruction of the spin density $\rho(x, y)$ is mathematically a two-dimensional Fouriertransformation of the signal intensity $\mathrm{SI}\left(k_{x}, k_{y}\right)$ from the encoding $k$-space to the coordinate space:

$$
\begin{aligned}
& \rho(x, y)=\iint \operatorname{SI}\left(k_{x}, k_{y}\right) \exp \left(-i k_{x} x\right) \exp \left(-i k_{y} y\right) d k_{x} d k_{y} \\
& \text { with } k_{x}=\gamma G_{x} t_{x}, k_{y}=\gamma G_{y} t_{y} .
\end{aligned}
$$

\section{Imaging Flow}

Monopolar gradient pulses encode space. If a gradient pulse $G$ acts over a time $t$, the spins acquire a phase shift $\phi=\gamma$ Gxt. In a symmetric bipolar pulse, the space-dependent phase shift will become zero, but only if the spin stays at their location $x$. If the spin move with a constant velocity $v$, than their phase shift will become proportional to its velocity, and an image of the velocity distribution $v(x, y)$ can be reconstructed (Fig. 1).

Water and oil have different resonance frequencies that can be excited separately. Therefore, the selective images can be obtained for both components. The velocity profiles are shown for different velocities. At higher velocities, the flow profile changes from pluglike to parabolic.

For water, this occurs earlier, and this will lead to a turbulent flow in the mixture (Fig. 2). A water layer

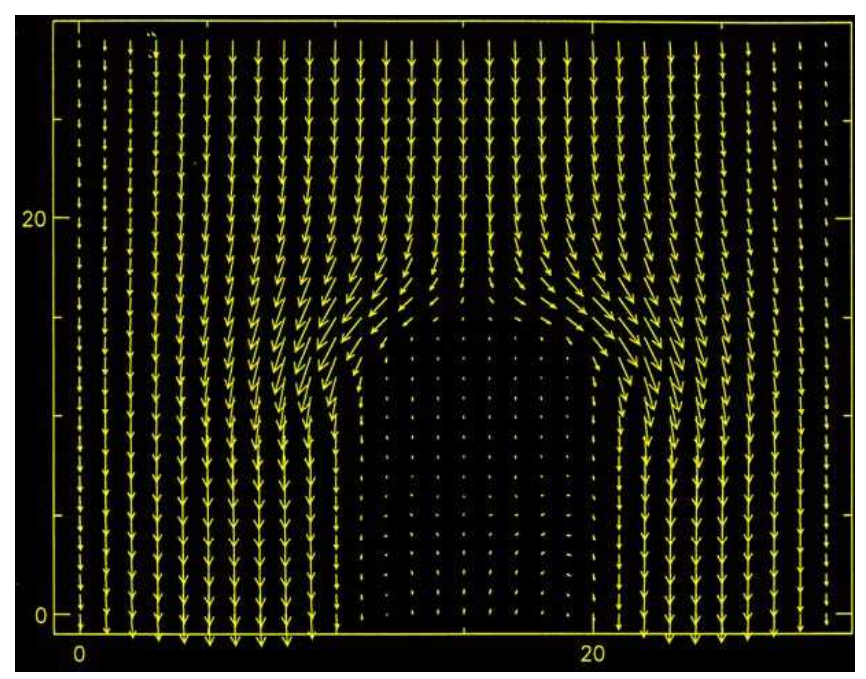

Fig. 1. Velocity distribution for the flow in a tube around a cylinder. Arrows indicate the value (length) and the direction of velocities 


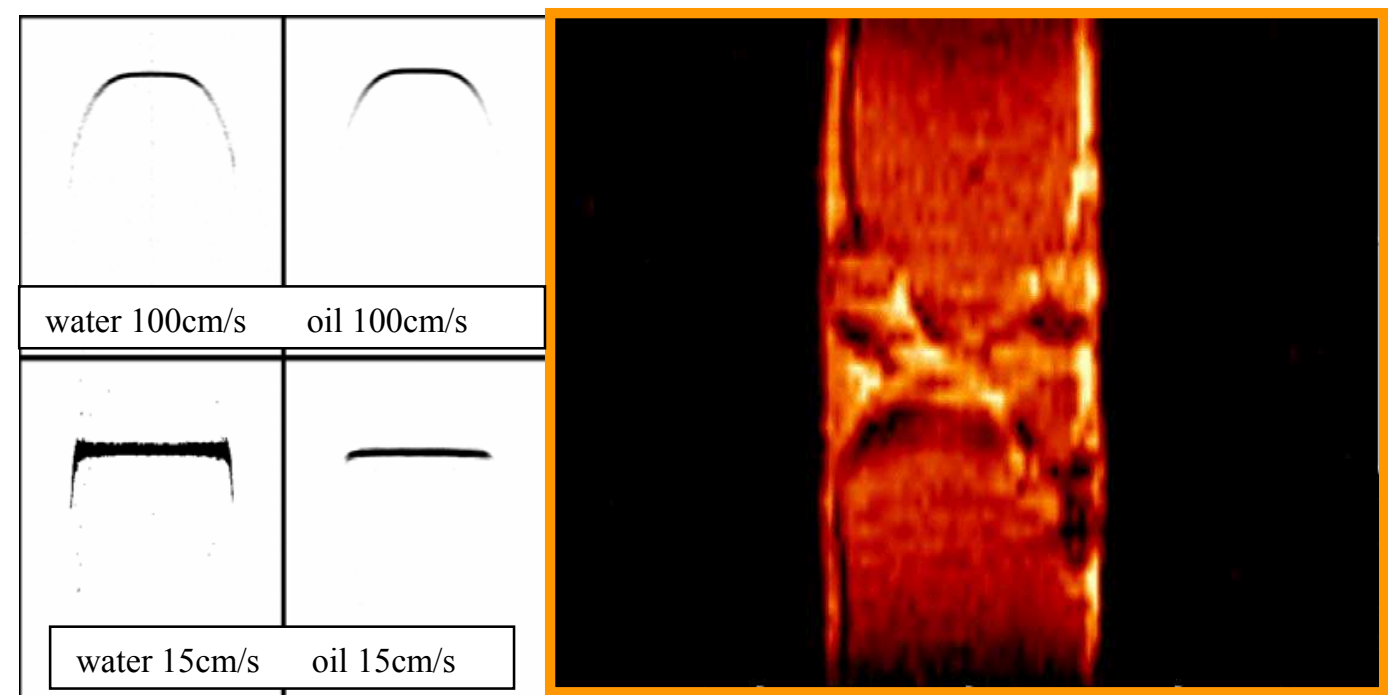

Fig. 2. Left: the radial velocity distribution flow of a two-phase liquid (water and oil) in a tube; right: the image of oil droplets in water in a tube of $12 \mathrm{~cm}$ at a velocity of $10 \mathrm{~cm} / \mathrm{s}$

covers the inner surface of a tube, and the mixture gets very inhomogeneous.

\section{NMR Rheology}

NMR rheology is another application of NMR to the physics of liquids to study the properties of complex fluids [1]. It combines NMR-microimaging and NMR spectroscopy and provides insight into the mechanical properties on a microscopic and even molecular level. The Bruker Biospin company in cooperation with P.T. Callaghan has developed a special Rheo-NMR-accessory for investigations in this field.

The investigation of non-linear viscoelasticity by Rheo-NMR requires that the deformational flow must be created within the rf coil inside an NMR magnet. A shaft is inserted into the magnet bore and driven by a stepper motor which is controlled by the spectrometer software, allowing experiments under complete automation. Rotation speeds in the range 0.08 to $4.74 \mathrm{~Hz}$ are available.

We have developed a wide variety of shearing and extensional flow cells, all of which can be mounted in the standard Bruker (wide-bore) microimaging probehead (see Table). Small deformation cells [4] in a microimaging system allow one to utilize quite small sample volumes and, therefore, to study expensive model materials, and the small cell dimensions give access to quite high strain rates. Because the cells are compatible with the standard Bruker micro-imaging probehead, it is possible to utilize the multinuclear capabilities of the rf coils and the temperature control features of the spectrometer system. Figure 3 shows, on the right, the drawing of a cone-and-plate cell mounted in the Bruker probe. In the Couette cell, two coaxial cylinders are rotated against each other. The inner cylinders are either smooth or finely crosshatched to inhibit a slip, and each has the capability of incorporating a marker fluid, so that the rigid body motion of the inner cylinder can be imaged in order to determine, by extrapolation, the cylinder surface velocity.

The really important questions in rheology concern the molecular basis of complex mechanical properties [2, 3]. When subjected to a stress, a solid will be deformed by a fixed amount and store the energy elastically. In contrast, a liquid flows and dissipates the energy continuously as viscous losses. In practice, many interesting materials in their condensed phase possess both solidsand liquid-like properties. We present the results of classical rheological measurements, where a material is subject to a deformation, and the stress $\sigma(t)$ is monitored as a function of the time-dependent strain $\gamma(t)$. The Newtonian behavior is characterized by a proportionality of the stress and the shear rate. In a shear thinning liquid, already small shear rates build up a strong stress, before the material begins to flow. Under the shear thickening, a material begins to flow already at minimal shear rates.

Below, we will be concerned with the large strain response, the so-called non-linear viscoelastic behavior. Complex fluids possess memory, which means that the stress they exhibit at any moment will generally depend on the history of a deformation. Their mechanical prop- 


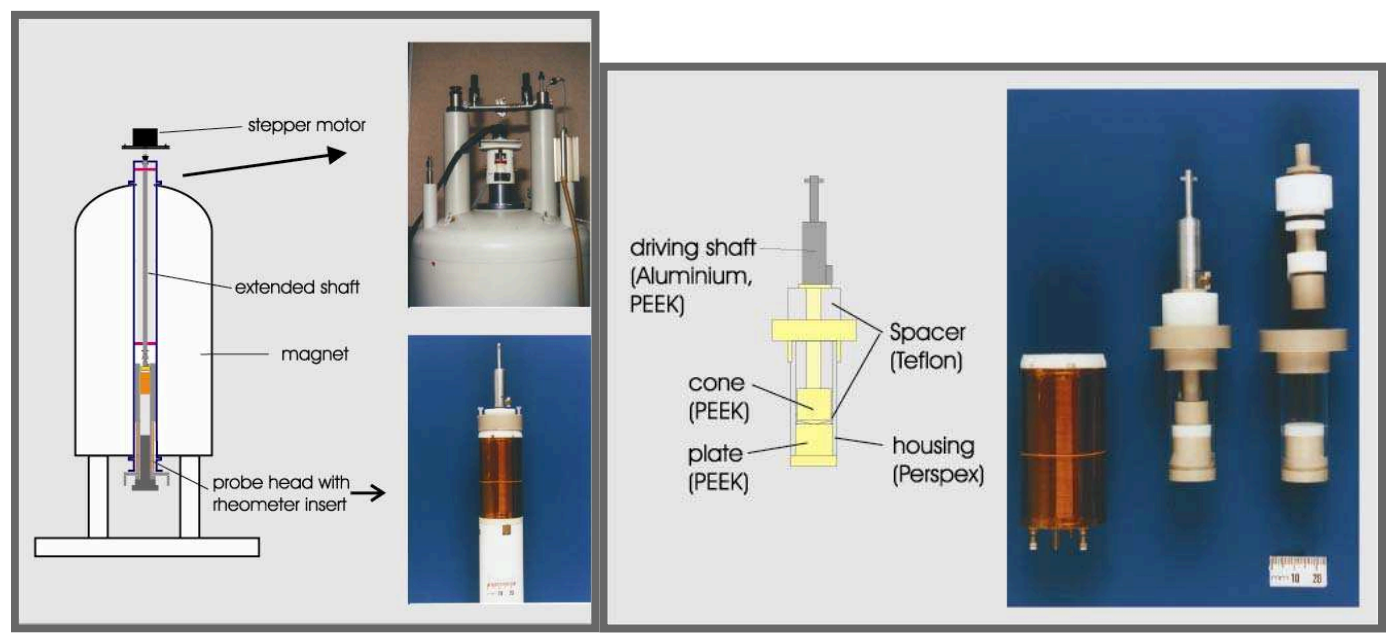

Fig. 3. Left: the mounting of a rheometric cell in a superconducting magnet; right: rheometric cells: "cone and plate"- and "Couette"-cell

Characteristics of rheometric cells for NMR microimaging

\begin{tabular}{|c|c|c|c|}
\hline $\begin{array}{c}\text { Rheometer } \\
\text { Type }\end{array}$ & $\begin{array}{c}\text { Dimensions }^{a} \\
(\mathrm{~mm})\end{array}$ & Material & $\begin{array}{l}\text { Shear Rate }\left(\mathrm{s}^{-1}\right) \text { at } \\
4.74 \mathrm{~Hz} \text { rotation rate }\end{array}$ \\
\hline $\begin{array}{l}\text { Cone-and- } \\
\text { plate }\end{array}$ & $\begin{array}{c}\text { cone diam.: } 24 \text { or } 16 \\
\text { angle: } 4^{\circ} \text { or } 7^{\circ}\end{array}$ & $\begin{array}{l}\text { machinable glass } \\
\text { (smooth) }\end{array}$ & 426 \\
\hline PEEK & ID: 19 & PEEK & 253 \\
\hline Couette cell & OD: 17 & (smooth or hatched) & \\
\hline PEEK & ID: 19 & PEEK & 536 \\
\hline Couette cell & OD: 18 & (smooth or hatched) & \\
\hline Glass & ID: 7.0 & smooth glass cylinder & 40 \\
\hline Couette cell & OD: 4.0 & Teflon bushes & \\
\hline Glass & ID: 9.0 & smooth glass cylinder & \\
\hline Couette cell & OD: 7.5 or 5.0 & Teflon bushes & 149 or 37 \\
\hline
\end{tabular}

${ }^{a} \mathrm{ID}$ : inner diam. of chamber; OD: outer diam. of rotor

erties can change as a deformation increases, which is the effect generally attributed to a molecular reorganization. NMR Rheology tries to understand the molecular basis of complex mechanical properties.

The pulse sequence to obtain velocity maps is a standard spin echo sequence and relies on the insertion of an additional pair of gradient pulses [5]. These so-called $q$ gradient pulses (duration $\delta$, separation $\Delta$, and gradient strength $g$ ) result in a phase shift of the echo signal as a function of the displacement of spins over the time interval $\Delta$.

Thus, the signal for each voxel corresponding to a pixel in the reconstructed image has a phase modulation factor $\Phi$ defined as $\Phi=\int P_{s}(Z, \Delta) \exp (i 2 \pi q Z) d Z$ with $q=\gamma g \delta / 2 \pi$, where $Z$ is the spin displacement along the gradient direction, $q$ is the reciprocal space vector,
$P_{s}(Z, \Delta)$ is the average propagator (the probability that a spin-bearing molecule will move by a displacement $Z$ in the time $\Delta$ ), and the integral is taken over the voxel volume. Typically, we acquire 8 separate $2 \mathrm{D}$ spatial images with different $q$ amplitudes in about 15 to $30 \mathrm{~min}$.

The Fourier-transformation along $q$ gives a picture of the propagator. The offset gives the velocity, and the width of the echo gives the diffusion coefficient.

The cone-and-plate cell exhibits an almost uniform stress across the fluid contained in the gap. Because the stress is approximately constant across the fluid, it is possible to use a cone-and-plate rheometer to step through the flow curve, point-by-point, by performing the corresponding $\sigma$ and $\gamma$ measurements. Regardless of whether a fluid is shear-thinning or shear-thickening, if the slip effects are absent, the shear rate across the gap 


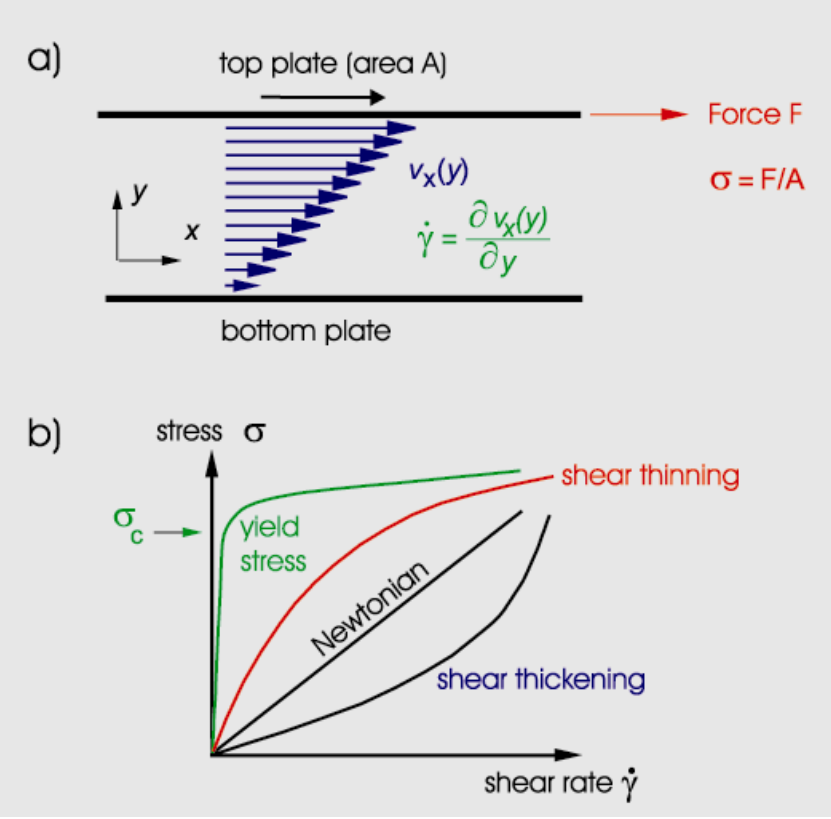

Fig. 4. Examples of flow courses $\sigma=$ stress $=$ force/area, $v=$ velocity, $\gamma=$ time-dependent strain

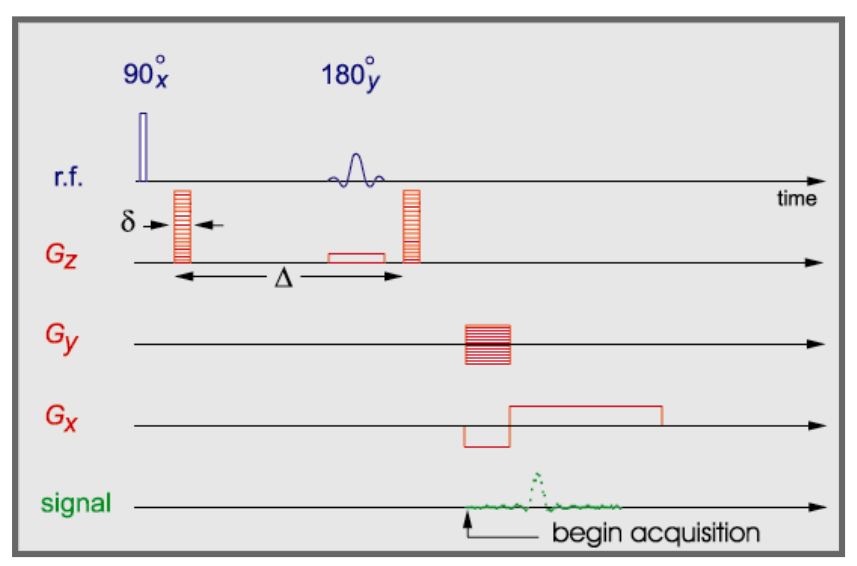

Fig. 5. Pulse sequence to obtain the velocity (displacement) and the diffusion coefficient

should be uniquely defined by the geometry. Thus, the cone-and-plate cell is the most popular device used to study the non-linear viscosity in complex fluids.

Figure 6 shows the normal velocity distribution in a cone-and-plate cell across a wormlike micelle solution (100 mM cetylpyridinium chloride, $60 \mathrm{mM}$ sodium salicylate). At low shear rates, the velocity proportional to the radius corresponds to a constant shear rate. But above a critical shear rate, the NMR flow visualization shows that the fundamental assumption of shear rate constancy is not valid for certain classes of fluids as

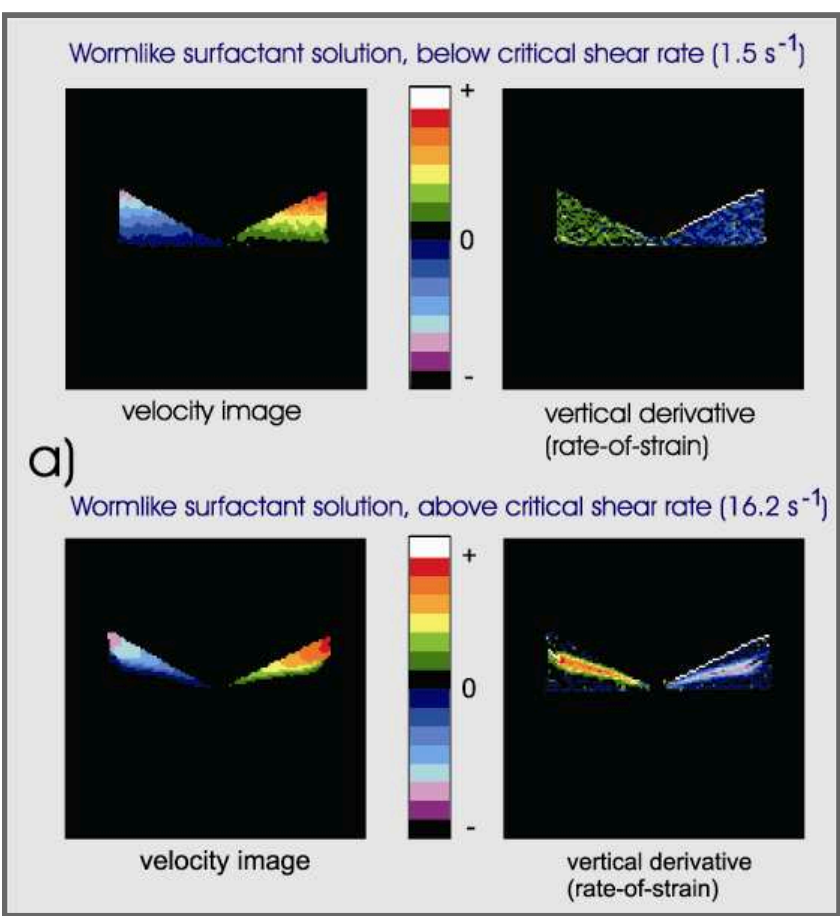

Fig. 6. Velocity distribution (left), the rate of strain (right) in a cone-and-plate cell across a wormlike micelle solution (100 mM cetylpyridinium chloride, $60 \mathrm{mM}$ sodium salicylate) below (top) and above a critical shear rate (bottom)

shown here (see also [6, 7]). A phenomenon known as the shear banding occurs, in which the fluid is apparently separated into coexisting phases of widely different viscosities.

Through the use of spectroscopic approaches, RheoNMR holds the promise of linking the mechanical and molecular properties. Amongst the spectroscopic tools which lend themselves to such studies are: (i) the measurement of spin relaxation times to gain information about a molecular rotational dynamics, (ii) the measurement of molecular diffusion coefficients in order to probe a molecular organization, and (iii) the measurement of ${ }^{1} \mathrm{H}$ dipolar interactions, ${ }^{13} \mathrm{C}$ chemical shift anisotropy, or ${ }^{2} \mathrm{H}$ quadrupolar interactions in order to gain information about a molecular alignment.

An example of the use of quadrupole interaction spectroscopy is presented in Fig. 7, where the shear-induced order in the wormlike micelle solution $\left(18 \% \mathrm{CTAB} / \mathrm{D}_{2} \mathrm{O}\right.$ at $40{ }^{\circ} \mathrm{C}$ ) is investigated [8]. The ${ }^{2} \mathrm{H}-\mathrm{NMR}$ spectrum of $\mathrm{D}_{2} \mathrm{O}$ is plotted as a function of the radial position across the gap of a cylindrical Couette cell. At the inner wall, where the stress is highest, a splitting is observed, which indicates a finite quadrupole interaction, while, at the outer wall, a single peak is observed. These 


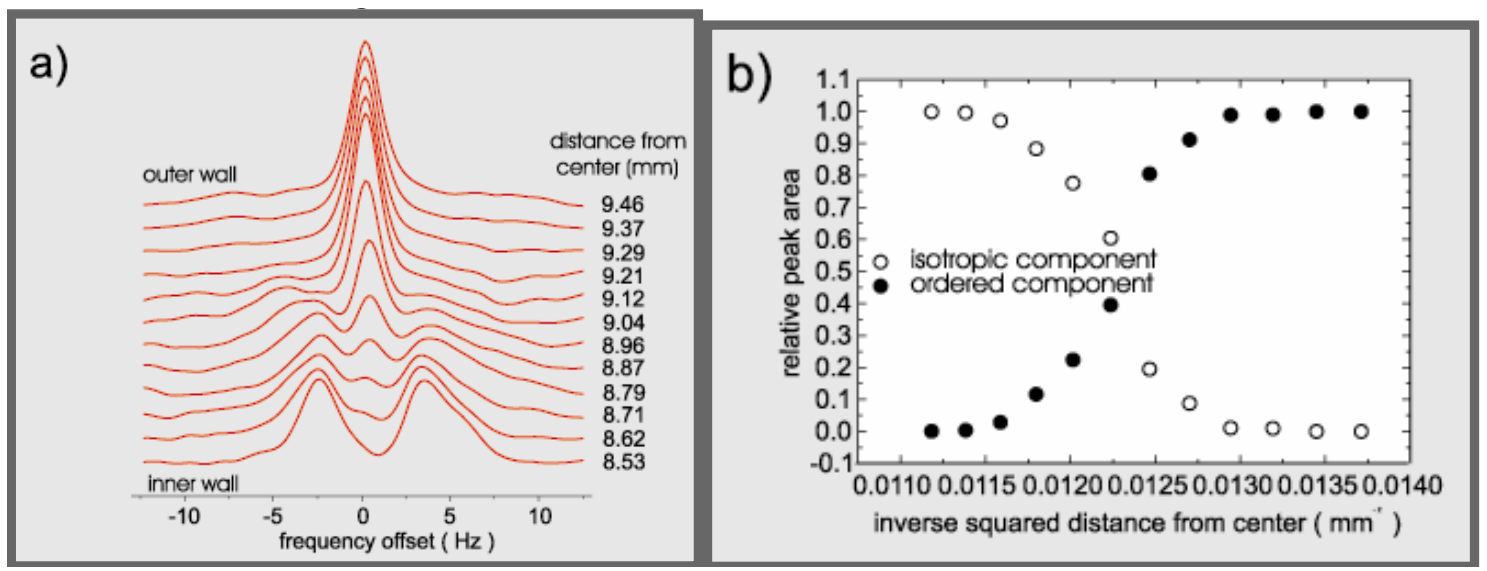

Fig. 7. ${ }^{2} \mathrm{H}$ spectra (left) and amount of the isotropic and stress-induced ordered nematic phases in a wormlike micelle solution (18\% $\mathrm{CTAB} / \mathrm{D}_{2} \mathrm{O}$ at $40{ }^{\circ} \mathrm{C}$ ) as a function of the radial position under stress in a cylindrical Couette cell

data suggest the formation of the nematic phase at high stresses with a transition through a mixed phase region to the isotropic phase at the region of low stresses. The relative peak areas of spectral components show the contributions of the isotropic and ordered components.

\section{Conclusion}

NMR imaging proves to be an excellent tool for the investigation of complex liquids on a microscopic level. The bulk velocity, velocity distribution, nonlinear stressstrain behavior, and stress-induced formation of oriented phases can be determined and monitored directly in the NMR images.

1. P.T. Callaghan, Reports on Progress in Physics 62, 599 (1999).

2. R.B. Bird, R.C. Armstrong, and O. Hassanger, Dynamics of Polymeric Liquids (Wiley, New York, 1987).

3. T.C.B. McLeish, Theoretical Challenges in the Dynamics of Complex Fluids (Kluwer, Dordrecht, 1997).

4. M.M. Britton, P.T. Callaghan, M.L. Kilfoil, E.W. Mair, and K.M. Owens, Appl. Magn. Reson. 15, 287 (1998).
5. P.T. Callaghan, Principles of Nuclear Magnetic Resonance Microscopy (Oxford Univ. Press, Oxford, 1993).

6. M.M. Britton and P.T. Callaghan, Phys. Rev. Lett. 78, 4930 (1997).

7. E.W. Fischer and P.T. Callaghan, Europhysics 50, 803 (2000).

8. P.T. Callaghan and A.M. Gil, Macromolecules 33, 4116 (2000).

Received 06.10.10

ВИЗНАЧЕННЯ ШВИДКОСТЕЙ МЕТОДОМ ЯМР ТА РЕО-ЯМР ТЕХНІКА ДЛЯ СКЛАДНИХ РІДИН

У. Ейчхоф, К. Цик, П.Т. Каллахен

Р ез ю м е

Із застосуванням техніки ЯМР визначено розподіл швидкостей та швидкість деформації в міцелярному розчині (хлорид цетилпіридиніуму та саліцилат натрію) нижче та вище критичної швидкості зсуву та досліджено ізотропну та індуковану напруженням впорядковану нематичні фази в міцелярному розчині цетил триметиламоніум бромид $/ \mathrm{D}_{2} \mathrm{O}$ у циліндричній комірці Куєтта. 